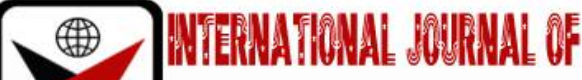

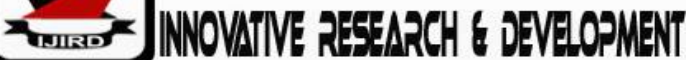

ISSN 2278 - 0211 (Online)

\section{Teachers' Attitudes toward Employing Morphological Awareness in the EFL Classrooms in Jordan}

\begin{tabular}{c}
\hline Samer Radwan Hmeadat \\
Ph.D. Student, Department of Languages and Communication, \\
Universiti Sultan Zainal Abidin, Malaysia \\
Kamariah Yunus \\
Professor, Department of Languages and Communication, \\
Universiti Sultan Zainal Abidin, Malaysia
\end{tabular}

\begin{abstract}
:
Morphological awareness plays an essential role in literacy. So many specialists and experts in the field of instruction confirmed the key role of morphological awareness to foster students' abilities to able to decode and spell words the right way. However, the current study was run to investigate the teachers' attitudes toward employing the knowledge of morphological awareness in the EFL classroom in Jordan and that was considered the ultimate goal and the study question. Thus, in order to carry out the study, a qualitative research method was administered through a research tool employed. The reliability and validity of the questionnaire were both beard in mind. The sample study consisted of (150) participants distributed in different municipalities in the Hashemite Kingdom of Jordan, especially in Zarqa municipality where the researcher works.

The findings of the study showed dearth in competence among teachers, besides, most of EFL teachers reduced the importance of morphological awareness as an approach to develop students' abilities to be competent readers and spellers. The results also revealed a clear gap in morphological awareness among the EFL teachers in part two of the questionnaire. Consequently, the researcher recommended other researchers to gear other studies on both teachers and students. Besides, the researcher recommended also EFL teachers to keep up to date revolutionary researches related to instruction methods.
\end{abstract}

Keywords: EFL teachers, morpheme, morphological awareness, inflectional and derived forms

\section{Introduction}

Looking for a solution to help students find their ways in learning English as a foreign language is a noble track. The problem of learning English is not only the learner's concern, but also parents, teachers, researchers and policy makers. However, problems that encounter EFL learners could be categorized in the four English skills according to their complexity; speaking, reading, writing and listening (Khawaldeh et al., 2016; Alrawashdeh and Al-zayed, 2016; Asessafeh., 2011; Rabab'ah, 2002). In this respect, morphological awareness is considered one of the main obstacles that encounter students in Jordan (Al-Sobhi and Preece, 2018; Naseeb and Ibrahim, 2017; Ramadan, 2015) especially among students in the first grade (Ashraf, 2018) which is considered the gate to the other grades during the school life (Sousa, 2017; Young, 2012).

However, a lot of Jordanian students suffer from different kinds of morphological problems such as misuse of morphemes, misuse of prefixes and derivations when they intended to construct antonymous words, misuse use of analogy, misuse of compounding and the interference of the mother tongue, Arabic, and a clear deficits in grammar (Naseeb and Ibrahim, 2017; Ramadan, 2015; Amber,2009).

\subsection{Morphological Awareness}

There are five domains of language; semantics (the meaning of words), syntax (sentence structure), pragmatics (communication), phonology (sound structure) (Fromkin, 2015; Braun, 2009; Rathvon, 2004) and morphology (internal structure of words, word formation, affixes and roots) (Lems, Miller and Soro, 2017; and Zibulsky and Cunningham,2014). In this paper, we want to discuss the morphological awareness and its impact on English Language Learners (ELLs) in Jordan. Morphology in general and morphological awareness in specific has been one of the fields that receive much heed among researchers, linguists, specialists and experts (Aram and Korat, 2009). The term 'morphological' is derived from morphology which is consisted of two morphemes (morph and ology) where the term 'ology' means study of kind of knowledge or the science of something, the term 'morph' refers to the smallest unit which has meaning. Further, morphology is the study of meaningful units and ways to make new words. Lems, Miller and Soro, 2017 and Fromkin ,2015 all indicated that if ELLs could succeed in dividing words into smaller meaningful bocks and they also could make 
associations among morphemes that constitute these words, then they would also excel in building their linguistic repertoire or the target vocabulary size.

\subsubsection{Some Cases of Morphological Awareness}

A morpheme has different shapes appear among words in various sentences (Fromkin, 2015). Here are some examples, a single phoneme within a word such as 'amoral' (Ibid) This word consists of two morphemes, ' $a$ ' means without and 'moral' means of or relating to principles of right and wrong in behavior (Merriam Webster, 2004). However, the word 'drinks' (drink as a basic infinitive verb and 's' signifies present simple) or the word 'boys', for example, which consists of two morphemes one of them is only one consonant with a sound (boy plus the consonant 's' refers to plurality). A morpheme also might be presented in two sounds such as in 'wanted', here the word involves two morphemes (want as a verb plus <ed>/Id/ as past simple marker) (Lems, Miller and Soro, 2017; Zibulsky and Cunningham,2014). Interestingly, morphs are presented either in a word form or phonetically. The previous examples when we used the ' $s$ ', this is accordingly, phonetic form. Meanwhile, the word moral itself represents a word form. And in order to understand what a morpheme is, you need to know that a morpheme is 'indivisible' to any smaller blocks (Brinton, 2000). Besides, a morpheme might be presented as a single syllable such as 'girl' or two syllables such 'girlish', or three syllables 'unhappiness' or faithfulness' and sometimes more than four syllables such as 'disestablishmentarianism' (dis+establish+ment+ari+an+ism) (Fromkin, 2015). Interestingly, a word sometimes has two syllables, but one morpheme such as the old English word 'father'. It has two syllables 'fa' and 'ther', but one meaningful block together that is not analyzable into other smaller units. Here is another example of an old English word, i.e. 'goodbye'. Accordingly, this word is a root that was consisted of four individual words 'God be with you', but with time, it became goodbye, so it is one morpheme that cannot be broken into any other smaller units (Lems, Miller and Soro, 2017). In order to make things more understandable, see table (1.1).

\begin{tabular}{|c|c|c|}
\hline Morphemes & Examples & Usage \\
\hline$-\mathrm{s}, \mathrm{es}$ & Watch(es)/Iz/, trees/z/, book(s) /s/ & To indicate plurality. \\
\hline -s,es & He go(es)/z/, she vist(s)/s/ & To indicate present simple markers. \\
\hline -ed & $\begin{array}{c}\text { John walk(ed), Reda need(ed)/Id/ } \\
\text { Hussein has work(ed)/t/ } \\
\text { He was interested. }\end{array}$ & $\begin{array}{l}\text { To indicate past simple marker. } \\
\text { To indicate past participle marker. } \\
\text { To indicate an adjective ending. }\end{array}$ \\
\hline $\begin{array}{c}\text {-er } \\
\text {-ster }\end{array}$ & $\begin{array}{c}\text { - He is a teach(er), present(er), danc(er) } \\
\text {-He is a songst(er) } \\
\text {-She is tall(er) }\end{array}$ & $\begin{array}{l}\text { - To indicate the one who does the } \\
\text { action. } \\
\text {-to indicate comparative. }\end{array}$ \\
\hline -est & - It is the fast(est) animal & -To indicate superlative. \\
\hline -or & -He is an act(or) & -To indicate the one who does the action. \\
\hline re- & Let's (re)write this sentence. & $\begin{array}{l}\text { To indicate repetition or doing } \\
\text { something again. }\end{array}$ \\
\hline Dis-, Un- & -(dis)construction, (un)believable & -To indicate the opposites \\
\hline
\end{tabular}

\subsubsection{Types of Morphology}

There are two related terms as we talk about morphology; descriptive morphology and cognitive morphology. Descriptive morphology signifies the systematic association between sound and meaning. Meanwhile, the other one indicates the mental images of patterns in the speaker's mind (Mansfield, 2019). Besides, Bybee (1985) indicated that although descriptive morphology cares much about the internal structure of the individual words, both cognitive and descriptive morphology contribute to reading comprehension and enhancing students' capacities to deal with morphemes with words and texts (Duncan et al.,2019).

\subsubsection{Types of Morphemes}

However, a morpheme might be spelled and pronounced in various ways among words and that depends on the phonemes around or the phoneme location within a word (Lems, Miller and Soro, 2017). For example, the morpheme 'medic' has three different spelling and pronunciations, medical, medicine and medication. Besides, there are two types of morphemes based on meaning according to Brinton (2000), grammatical morphemes and lexical morphemes (dictionary meaning). Where the former represents meaning of words according to context and they depend more on prepositions, articles, helping verbs, and demonstrative pronouns. It is also related to other parts of words such as prepositions (Zibulsky and Cunningham, 2014). The latter represents open categories and the word classes; verb, noun, adjective and adverb. Besides, lexical morphemes are generally autonomous words or root words (Zibulsky and Cunningham, 2014; Brinton,2000). And here is a direct indication to the importance of meaning and to the strong relationship between morphological awareness and comprehension because morphological awareness which relies on meaning develops comprehension (Duncan et al., 2019). The following figure illustrates the two types of morpheme (Brinton, 2000, p76) 


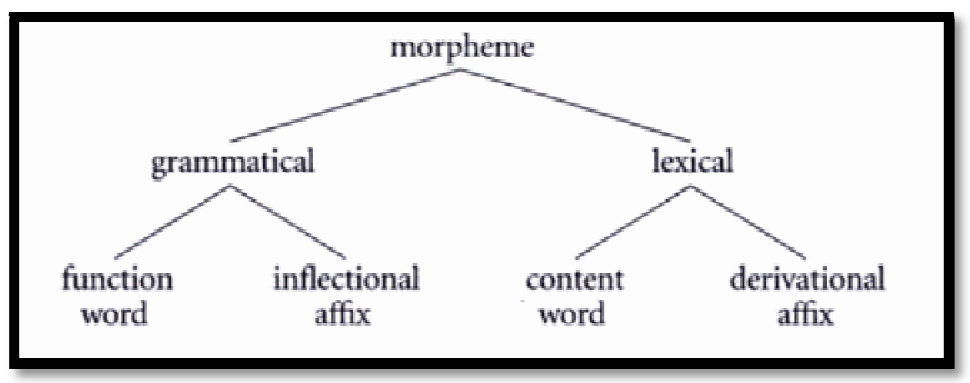

Figure 1: Shows the Types of Morphemes

\subsubsection{Inflectional and Derivational Morphemes}

First of all, let's discuss the definitions of both terms. Inflection refers to a form that is added to the ended of words to indicate tense, plurality comparison or to maintain a word class i.e. the word 'played' involves both the root form 'play' and the past tense marker ' $e d$ ' to indicate both the past tense and the past participle from a side and to indicate the same word class as a verb' (Fromkin, 2015; Treiman, 1993). Besides, here is the word 'books', in this example, the morpheme ' $s$ ' is added after the root word (book) maintaining the same meaning. In other words, adding the suffix ' $s$ ' does not change the word class as a noun. The word 'adult alike', here the root form is 'adult' and the suffix are 'alike' to indicate comparison. Consequently, the inflectional morphemes reflect grammatical information, tense, person and number (Eppler and Ozón, 2013).

In contrast, in the light of derivational morphemes, the situation is different, the addition might be initially, medially or in a final position which means that a derivational form might be a prefix or a suffix (Lems, Miller and Soro, 2017; Salim, 2013). The word (i.e. dishonest) is an example of a derivational morpheme where the addition comes before the root as a prefix and it changes the meaning of the root form. As a result, the meaning of any word depends mainly on two things; the morpheme itself and its occurrence (Treiman, 1993; Salim, 2013). As there are various types of morphemes, there are also two types of morphs. But these are essentially based on form but not the meaning itself.

\subsubsection{Types of Morphs}

There are two categories of morphs; free morphs (parts) and bound morphs (parts). Free morphs are the ones that can stand by their own and do not need any affixations because they represent root words and they are not segmented into any other smaller meaningful and grammatical units, for example 'door, hand, boy and car'. Accordingly, these words are not any further analyzable. Interestingly, each single word in English must involve a free morpheme (Denham and Lobeck, 2010; Eppler and Ozón, 2013). Further, the free morphemes involve both the closed class such as conjunctions (and, but), prepositions (in, on, for), articles (an, the) and auxiliary verbs (is and are) and the open class category such as nouns (boy), verbs (jump) and adjectives (slow) and adverbs (quickly) (Fromkin, 2015). In contrast, the bound parts (affixes) need other word forms to be able to stand and they need to be attached to other forms i.e. waits, driving, sharks and walked or i.e. ish, ment, ous and er (Fromkin, 2015; Eppler and Ozón, 2013; Rathvon,2004; Denham and Lobeck, 2010). It is worth mentioning here that some roots are considered as bound morphs because they were borrowed from other languages where they were free in origin, but not anymore exist in English but this is not a rule because in English we have always exceptions. Here is an example about a word borrowed i.e 'vert' in the English word 'convert'. This root was derived from Latin, but in English, it cannot stand alone (Brinton,2000).

\subsubsection{Prefixes and Suffixes}

Unlike roots, affixes are as morphemes (Lems, Miller and Soro, 2017) classified in English into three groups; prefixes, suffixes (Fromkin, 2015; Rathvon, 2004) and infixes (very fewer in English and they are employed for entertaining purposes) (Brinton, 2000). Similarly, both, prefixes and suffixes, are attached to a root or base form. Here are some examples of prefixes, of course, which attached to the left side of the root; 'dis, un, il, ir, re, for and en'. Further, the following morphemes 'un, in, re, dis' represent $58 \%$ of all words with prefixes (O'Connor, 2007). Whereas, some suffixes which are attached after the root forms such as; '-ing, -ed,-ly,-er, -or,-tion, -sion, -ible, -able, -al, -y and -ness' (Lems, Miller and Soro, 2017; Fromkin, 2015; Denham and Lobeck, 2010, Rathvon,2004) represent 60\% of word endings (O'Connor,2007). All affixes as we mentioned earlier are bound forms (Bauer et al., 2013). Interestingly, O'Connor (2007) also indicated that although 're-' is considered a prefix, but students should pay attention to words such as 'read and really' where 're' does not function as a phoneme. Here, according to these examples, 're' is not considered as a morpheme.

However, there are two ways to construct complex words, affixation and compounding. By affixation, you can use the inflectional or derivational forms to create new words changing meaning of the root word or the word class of the root word, too. i.e. the root word is 'happy', it becomes 'unhappy' and here the meaning of the words has changed but still an adjective. 'happily' also is created through adding ' $l y$ ' to the root word as derivational form changing the word class from an adjective to adverb (Rathvon,2004). The other way to create new words is through compounding which is considered as a word formation technique; by the addition of two morphemes or lexemes such as teapot, seabird and weekend.

\subsection{Problem Statement}

The Minister of Education in Jordan, Dr. Mohammed Thneibat asserted that 22\% of primary grades could not read or write (Al Shaboul, 2016). Further, according to so many researchers, students in Jordan suffer from severe problems in 
reading and writing because of deficits in morphological awareness caused by various factors such as insufficient methods of instruction and limited competence of EFL teachers (Elttayef and Hussein, 2017; Naseeb and Ibrahim,2017).

\subsection{Research Question}

The ultimate purpose of this research was to highlight an issue and try to investigate a research question and find out an appropriate solution. Different questions arose trying to understand the problems EFL teachers face during their service regarding morphology and the problems faced by their students during their learning English as a foreign language. However, the basic question for the current research is "What are the teachers' attitudes toward employing the morphological awareness skills in the EFL teachers' daily lessons in Jordan?"

\subsection{Research Objectives}

This study aims at highlighting the teachers' attitudes toward morphological awareness and its employing in the EFL classroom in Jordan. Besides, it sheds light on to what extent teacher really recognize the importance of assigning a short period of time to teach morphological awareness during their daily sessions. Further, the study is described as an extension of other research studies in the same field and aims to enrich its literature.

\subsection{The Significance of the Study}

The study is an endeavor to deepen the knowledge of morphological awareness among the EFL teachers in Jordan. It tries to pay attention to the importance of being morphologically aware either as a teacher or as a student and clarify the components of morphological awareness as an autonomous and independent field in the applied linguistics. It aims to help curricula designers to create fruitful textbooks that help both learners and teachers develop their linguistic competence. Besides, this study represents a cornerstone for other practical studies to help both teachers and learners identify sources of problems in the fields of reading and writing (spelling).

\subsection{Limitations of the Study}

The current study involved this sample size which consisted of (150) male and female EFL teachers. Further, the study was carried out in the academic year 2019-2020. Besides, this study was restricted to investigate the EFL teachers' attitudes toward employing the morphological awareness in the EFL classroom.

\section{Literature Review}

\subsection{Related Studies about Morphological Awareness}

The study of Bataineh and Kofeiri (2018) investigated the effect of morphological awareness on the tenth-grade students' reading comprehension in Jordan through a training intervention which lasted for 10 weeks. Further, the teacher who implemented the training took a special and intensive training for four days. Besides, the sample of the study was ( $\mathrm{N}=$ 73) participants from the grade 10 who were chosen purposefully in the city of Rumtha. These participants were divided into two groups; the experimental group $(\mathrm{N}=37)$ who were taught through a training program based upon morphological awareness, and control group $(\mathrm{N}=36)$ who were taught through the conventional strategy which is employed by the most English teachers in Jordan. A quantitative design based on pre-test and post-test was used. Consequently, the results of the study showed that the students who were undertaken to a morphological training intervention outperformed and achieved statistically significant development in reading comprehension compared to the control groups who taught through the traditional approach. Recommendations of the study were to incorporate morphological awareness in the content taught by the EFL teachers, and to make morphological awareness a threshold before teaching reading comprehension.

Moreover, the study of Kirby and Bowers (2010) also investigated the effect of a morphological intervention on vocabulary knowledge. The sample study consisted of (81) students from the fourth and fifth grades. The participants were randomly assigned to (38) students as experimental groups and (43) students as control groups. The questions of the study mainly focused on the role of morphological structure and to what extent they affect vocabulary learning. The design of pre-test and post-test design was employed. Besides, the Peabody Picture Vocabulary Test III which consisted of 30 words, was also used and was run individually. Findings of the study showed to what extent the training was successful and fulfilled the outcomes of the intervention. Besides, the experimental groups also outperformed compared to the untrained control groups. Further, the students could master morphological linguistic patterns successfully. Moreover, the students were competent readers and could develop build up their repertoire. The study stressed the association between the orthography system and the meaning of words.

\subsection{Morphological Awareness, Repertoire (vocabulary) and Comprehension}

The words in English are naturally morphophonemic, which refers to the fact that English involves "phonemic and morphological information" (Lems, Miller and Soro, 2017, p 113). Further, morphological knowledge depends mainly on real knowledge of morphemes, their pronunciations, their meanings and mastering the rules govern these morphemes (Fromkin, 2015). Therefore, the association between reading comprehension and morphological aspect is strong (Bataineh and Al Kufeiri,2018). Further, Duncan et al., (2019) also indicated also that comprehension relies much on morphological awareness and that children who are unaware morphologically. Besides, another factor that affects morphological knowledge is vocabulary size whether receptive because students know these vocabularies but they do not employ them in their daily life whether in writing or in speaking as a productive form. The term 'productively' refers to the 
ability of students to use these words in speaking and writing and this process is accordingly considered as an active process (Hidri, 2018; Susanto, 2017; Lapp and Fisher, 2011; Kirby and Bowers, 2010). Accordingly, the relation between morphology and word knowledge is robust and strong especially words that have the same morpheme (Lems, Miller and Soro, 2017).

Some think that one of the ultimate goals of teaching vocabulary is to acquire new meanings which serve directly in enhancing morphological knowledge (Shearer et al., 2019; Kirby and Bowers, 2010). Accordingly, word knowledge contributes to foster students' capacities to be more aware of the root forms and morphemes. Besides, Duncan et al., (2019) indicated that any reading development should mainly depend on the knowledge of morphological awareness in general and the knowledge of the derived forms and inflectional patterns in specific. They even went further when they asserted that morphological awareness is a must to be able to read. Besides, Hartranft and Silverman (2015) also stressed the importance of evaluating students' abilities to understand new words based on their previous knowledge of word parts through employing different tasks such as compounding tasks, inflectional tasks and derived morphological tasks. Consequently, the more students are aware of words and word roots, the best experience they will acquire about words and new words. Hartranft and Silverman (2015) also confirmed to what extent it is important to morphological awareness should be taught in the early grades due to the positive gains in reading and writing development. Hidri (2018) in this respect indicated that learners can use dictionary approach for further help in order to know the different inflectional derived forms of words. Besides, they can employ the guessing approach, which is better, in order to study words implicitly and dependently. As a result, the approach of guessing enables students to be self-taught readers (Hidri, 2018; Susanto, 2017).

However, Hidri (2018.p 243) indicated that vocabulary knowledge involves four basic components; "vocabulary size, the depth of vocabulary knowledge, lexical organization and automaticity of receptive-productive knowledge". Accordingly, the receptive-productive knowledge includes phonological and morphological knowledge. In the light of the importance of vocabulary, Hidri (2018.p244) stressed that "there are four types of vocabulary in any text; high frequency words ( 2000 words), academic ( $9 \%$ of the running words in a text), technical ( $5 \%$ of the running words and can be found in technical dictionaries) and low frequency words (these represent the majority of words in English these represent $5 \%$ of the running words in a text)".

Moreover, Susanto (2017) also indicated that vocabulary students help them to process the words they meet in a text through thinking about and reflecting upon the roots, lexical morphemes and origin of the words and vocabulary knowledge is also considered an individual achievement that enable students use a language in all its aspects, writing, speaking (productively) reading and listening (implicitly). The capacity to equip students with morphological awareness means the ability to develop reading comprehension among students and create special kind of students who are consciously and subconsciously sensitive to word patterns (Bataineh and Al Jofieri,2018). Further, Kirby and Bowers (2010) also indicated the role of morphological awareness to develop competent students who have enough vocabulary size and are able to comprehend any text because of the morphological sensitivity they acquired.

\section{Methodology}

The researcher employed a qualitative research method that involved qualitative designs for the validation of the research findings. The qualitative research used statistical methods so that the researcher can analyze the data collected. However, the questionnaire was modified over and over by the researcher to meet and fulfill the Jordanian EFL teachers' needs. This instrument as a questionnaire was revised by a panel of judges. Accordingly, it has been adjusted by addition or deletion when necessary.

\subsection{Sample of the Study}

The population of this study consisted of all the EFL teachers in Az Zarqa 1 ${ }^{\text {st }}$ Directorate of Education, Az Zarqa. The sample consisted of (196) male and female participants who were selected randomly in order to explore the teachers' attitudes toward employing the morphological awareness in the EFL classrooms.

\subsection{Tools of the Study}

The researcher run a qualitative research through employing a judged questionnaire to search and highlight the attitudes of EFL teachers distributed in different places in the Hashemite Kingdom of Jordan toward the use of morphological awareness as an explicit instruction model. Validation and reliability of the questionnaire were administered. The data collected was analyzed through SPSS. Besides, a pilot study of (30) respondents was done.

\subsection{A Questionnaire}

For the sake of validity, the current questionnaire was headed to sample of EFL teachers in widespread different areas in Jordan. A pilot study of the questionnaire was run on (30) EFL teachers (outside of the sample) to test the reliability of the current questionnaire. The questionnaire involved two parts; the first one consisted of (13) related statements about the main topic covering the important issues regarding the general knowledge of the respondents and the second part comprised (16) direct practical multiple choice questions to measure the real teachers' morphological awareness knowledge among the EFL teachers in order to reach their practical level of morphological awareness knowledge. Interestingly, the current questionnaire was conducted during the outbreak of the pandemic Coronavirus, the late of June 2020- the beginning of July 2020. Therefore, the questionnaire was conducted online. 


\subsubsection{Validation}

The questionnaire was exposed to a panel of judges for the purpose of validation. Their remarks and suggestions were taken seriously into considerations.

\subsubsection{Reliability}

For the purpose of reliability, a pilot study consisted of (30) respondents were run. Cronbach's Alpha of part one was calculated (0.811). Meanwhile, Cronbach's Alpha of part two was (0.751). See table (2.1).

\begin{tabular}{|c|c|c|c|}
\hline Questionnaire's Parts & Cronbach's Alpha & & \\
\hline Part one & 0.811 & & \\
\hline Part two & 0.751 & & \\
\hline \multicolumn{4}{|c|}{ Case Processing Summary (Part One) } \\
\hline & & $\mathrm{N}$ & $\%$ \\
\hline \multirow[t]{3}{*}{ Cases } & Valid & 30 & 100 \\
\hline & Excludeda & 0 & 0 \\
\hline & Total & 30 & 100 \\
\hline \multicolumn{4}{|c|}{ a. Listwise deletion based on all variables in the procedure. } \\
\hline \multicolumn{4}{|c|}{\begin{tabular}{|l|l|l} 
Reliability Statistics of Part One & & \\
\end{tabular}} \\
\hline Cronbach's Alpha & $\mathrm{N}$ of Items & & \\
\hline 0.811 & 13 & & \\
\hline \multicolumn{4}{|c|}{ Case Processing Summary of Part Two } \\
\hline & & $\mathrm{N}$ & $\%$ \\
\hline \multirow[t]{3}{*}{ Cases } & Valid & 30 & 100 \\
\hline & Excludeda & 0 & 0 \\
\hline & Total & 30 & 100 \\
\hline \multicolumn{4}{|c|}{ a. Listwise deletion based on all variables in the procedure. } \\
\hline \multicolumn{4}{|c|}{\begin{tabular}{|l|l} 
Reliability Statistics of part two & \\
\end{tabular}} \\
\hline Cronbach's Alpha & $\begin{array}{l}\text { Cronbach's Alpha } \\
\text { Based on } \\
\text { Standardized Items }\end{array}$ & $\begin{array}{l}\mathrm{N} \text { of } \\
\text { Items }\end{array}$ & \\
\hline 0.751 & 0.75 & 16 & \\
\hline
\end{tabular}

Table 2: Shows Cronbach's Alpha for Each Part of the Questionnaire

\section{Results}

\begin{tabular}{|c|c|c|c|c|}
\hline \multicolumn{2}{|c|}{ Region and Governorates } & Frequency & Percent & Valid Percent \\
\hline North & Irbid & 46 & 23.5 & 23.5 \\
\cline { 2 - 5 } Region & Ajlun & 6 & 3.1 & 3.1 \\
\cline { 2 - 5 } & Jerash & 7 & 3.6 & 3.6 \\
\hline Central & Mafraq & 7 & 3.6 & 3.6 \\
\cline { 2 - 5 } Region & Amman & 47 & 24.0 & 24.0 \\
\cline { 2 - 5 } & Balqa & 10 & 5.1 & 5.1 \\
\cline { 2 - 5 } & Zarqa & 28 & 14.3 & 14.3 \\
\cline { 2 - 5 } & Madaba & 8 & 4.1 & 4.1 \\
\hline South & Kegion & 11 & 5.6 & 5.6 \\
\cline { 2 - 5 } & Tafila & 10 & 5.1 & 5.1 \\
\cline { 2 - 5 } & Ma'an & 7 & 3.6 & 3.6 \\
\cline { 2 - 5 } & Aqaba & 9 & 4.6 & 4.6 \\
\hline & Total & 196 & 100.0 & 100.0 \\
\hline
\end{tabular}

Table 3: Shows Respondents Belong to Their Governorates

The previous tables show the number of respondents regarding the cities they belong to. The highest number of participants belonged to the city of Irbid with frequency (46) respondents. The previous table also shows that the questionnaire could cover all the regions and governorates (North, central and south) of Jordan which allow the researcher to generalize the results. 


\begin{tabular}{|l|c|c|}
\hline \multirow{2}{*}{ Valid } & Male & Frequency \\
\cline { 2 - 3 } & Female & 72 \\
\cline { 2 - 3 } & Total & 124 \\
\hline
\end{tabular}

Table 4: Statisitcs of Sex

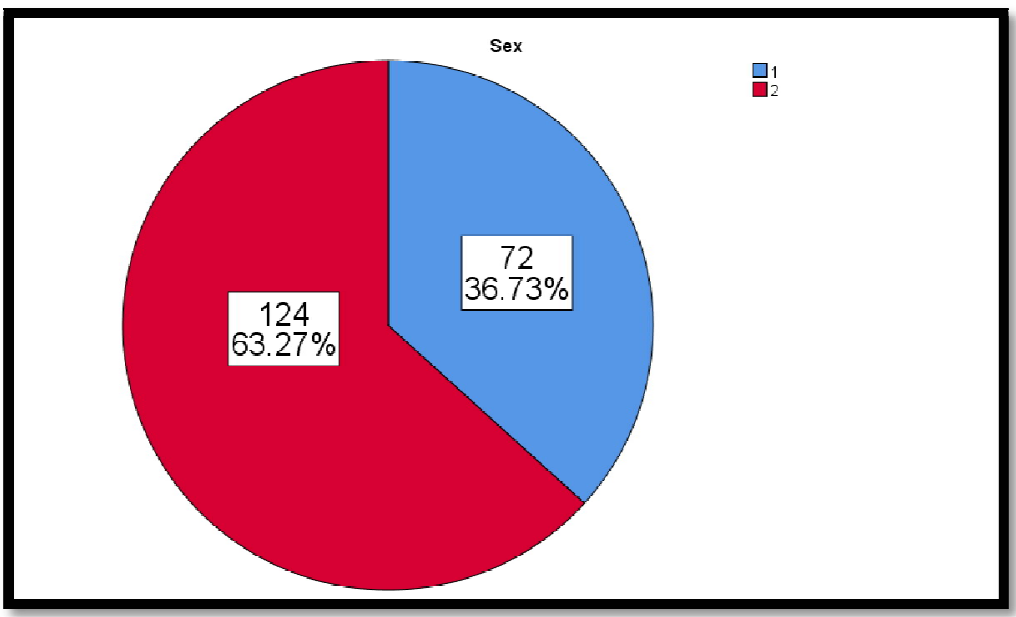

Figure 2: Shows Percentages of Respondents Attributed to Sex

\begin{tabular}{|c|c|c|c|c|}
\hline \multicolumn{2}{|c|}{} & Frequency & Percent & Valid Percent \\
\hline Valid & No Experience at all & 8 & 4.1 & 4.1 \\
\cline { 2 - 5 } & Beginner Teacher (1-2) & 16 & 8.2 & 8.2 \\
\cline { 2 - 5 } & 3-5 Years & 52 & 26.5 & 26.5 \\
\cline { 2 - 5 } & 6-10 Years & 64 & 32.7 & 32.7 \\
\cline { 2 - 5 } & 11-15 Years & 46 & 23.5 & 23.5 \\
\cline { 2 - 5 } & More than 16 Years & 10 & 5.1 & 5.1 \\
\cline { 2 - 5 } & Total & 196 & 100.0 & 100.0 \\
\hline
\end{tabular}

Table 5: Shows Years of Experience

\begin{tabular}{|c|c|c|c|c|}
\hline \multicolumn{2}{|c|}{} & Frequency & Percent & Valid Percent \\
\hline \multirow{3}{*}{ Valid } & Diploma & 8 & 4.1 & 4.1 \\
\cline { 2 - 5 } & Bachelor Degree & 175 & 89.3 & 89.3 \\
\cline { 2 - 5 } & Higher Studies & 13 & 6.6 & 6.6 \\
\cline { 2 - 5 } & Total & 196 & 100.0 & 100.0 \\
\hline
\end{tabular}

Table 6: Shows Certification of Respondents

\begin{tabular}{|c|c|c|c|c|}
\hline \multicolumn{2}{|c|}{} & Frequency & Percent & Valid Percent \\
\hline Valid & No courses at all & 11 & 5.6 & 5.6 \\
\cline { 2 - 5 } & $1-3$ courses & 171 & 87.2 & 87.2 \\
\cline { 2 - 5 } & $4-7$ courses & 4 & 2.0 & 2.0 \\
\cline { 2 - 5 } & More than 8 courses & 10 & 5.1 & 5.1 \\
\cline { 2 - 5 } & Total & 196 & 100.0 & 100.0 \\
\hline
\end{tabular}

Table 7: shows Training Courses of Respondents

\subsection{Analysis of Part One}

The first part of the questionnaire comprised 13 items. The respondents had to choose one of the 5-points Likert Scale. Looking closely at each item, we find out that 70 respondents strongly agree with the item number one which says that Morphological awareness is a course which I as a respondent studied at university. Meanwhile, 42 strongly disagreed. Regarding employing morphological awareness in daily lessons, 53 of respondents disagreed with the item which says that I employ morphological awareness in my daily lesson.

Further, 59 of respondents strongly disagreed with the item that says "I know well that morphological process involves five basic components such as, affixation, internal change, suppletion, zero-modification and compounding. Meanwhile, 59 disagreed and 40 respondents were neutral.

Regarding the ability to distinguish between derivational and inflectional affixes, 66 respondents disagreed the item that says "I can easily distinguish between inflectional and derivational affixes" and 41 strongly disagreed.

Regarding teaching phonological awareness to primary grades, 80 respondents strongly disagreed. In contrary, only, 32 respondents strongly agreed. Pertaining to teaching morphological awareness to elementary grades (Grades from 4-10), 55 respondents disagreed. In contrast, 65 respondents agreed to teach morphological awareness to elementary grades. 
This percentage increased when the item headed the same question to respondents about their attitudes to teach morphological awareness to secondary grades (11 and 12). 77 of respondents agreed to teach this content to secondary grades. Meanwhile, 30 of respondents strongly disagreed. Interestingly, 71 of respondents strongly disagreed with the item that says that "I think morphological awareness is a higher level that is too early to be taught at schools. In contrast, 28 of respondents strongly agreed with that.

Pertaining the item that says that "morphological awareness is a learnable skill that can be taught at school, 52 of respondents were neutral. 44 of respondents strongly disagreed, in contrary, and 28 of respondents strongly agreed. Here is the Descriptive Statistics of the 13 items of the questionnaire as seen in table (1.6).

\begin{tabular}{|c|c|c|c|}
\hline & Mean & Std. Deviation & Analysis N \\
\hline $\begin{array}{l}\text { 1. Morphological Awareness is a } \\
\text { course which I studied at the } \\
\text { university. }\end{array}$ & 3.4286 & 1.56238 & 196 \\
\hline $\begin{array}{l}\text { 2. I employ morphological } \\
\text { awareness in my daily lesson. }\end{array}$ & 2.8163 & 1.51808 & 196 \\
\hline $\begin{array}{l}\text { 3. The association between } \\
\text { morphological awareness and } \\
\text { spelling is positive and strong. }\end{array}$ & 3.2704 & 1.44412 & 196 \\
\hline $\begin{array}{l}\text { 4. I know well that } \\
\text { morphological process involves } \\
\text { five basic kinds such as stem } \\
\text { structure and derivation. }\end{array}$ & 2.6939 & 1.35804 & 196 \\
\hline $\begin{array}{l}\text { 5. Morphological Awareness is a } \\
\text { learnable skill that can be taught } \\
\text { at schools. }\end{array}$ & 2.7857 & 1.34164 & 196 \\
\hline $\begin{array}{l}\text { 6. I can easily distinguish } \\
\text { between inflectional and } \\
\text { derivational affixes. }\end{array}$ & 2.8010 & 1.44868 & 196 \\
\hline $\begin{array}{l}\text { 7. Derivational suffixes can occur } \\
\text { initially, medially and finally } \\
\text { within a word. }\end{array}$ & 3.2704 & 1.53701 & 196 \\
\hline $\begin{array}{l}\text { 8. I quite realize that the } \\
\text { meaning of the word depends } \\
\text { upon the morphemes and its } \\
\text { occurrence. }\end{array}$ & 3.1224 & 1.21752 & 196 \\
\hline $\begin{array}{l}\text { 9. I know well that inflectional } \\
\text { derivation occurs after the root. }\end{array}$ & 3.1224 & 1.43770 & 196 \\
\hline $\begin{array}{l}\text { 10. I think it is fruitful and } \\
\text { applicable to teach } \\
\text { Morphological Awareness for the } \\
\text { primary grades }\end{array}$ & 2.4031 & 1.49728 & 196 \\
\hline $\begin{array}{l}\text { 11. I think it is fruitful and } \\
\text { applicable to teach } \\
\text { Morphological Awareness for the } \\
\text { elementary grades }\end{array}$ & 3.0561 & 1.38930 & 196 \\
\hline $\begin{array}{l}\text { 12. I think it is fruitful and } \\
\text { applicable to teach } \\
\text { Morphological Awareness for the } \\
\text { secondary grades }\end{array}$ & 3.3980 & 1.38668 & 196 \\
\hline $\begin{array}{l}\text { 13. I think MA is a higher level of } \\
\text { thinking that is too early to be } \\
\text { taught at schools }\end{array}$ & 2.3214 & 1.41919 & 196 \\
\hline
\end{tabular}

Table 8: Shows the Descriptive Statistics of the 13 Items

Regarding factor analysis among variables, as known, a correlation which is close to 0 indicates no linear relationship between variables. The sign indicates the direction of the relationship. Accordingly, the correlation between the item 8 which says that "I quite realize that the meaning of the word depends upon the morphemes and their occurrence" with item number 9 which says "I know well that inflectional derivation occurs after the root". The correlation between these items is $(-0.208)$ is weak. Further, most the correlation between items are basically non-linear. They are not correlated. 


\begin{tabular}{|c|c|c|}
\hline \multicolumn{2}{|c|}{ Kaiser-Meyer-Olkin Measure of Sampling Adequacy. } & $\mathbf{. 4 8 1}$ \\
\hline \multirow{2}{*}{ Bartlett's Test of Sphericity } & Approx. Chi-Square & 97.841 \\
\cline { 2 - 3 } & $\mathrm{df}$ & 78 \\
\cline { 2 - 3 } & Sig. & .064 \\
\hline
\end{tabular}

Table 9: Shows KMO and Bartlett's Test

According to the Previous Table (1.7), the Factor Analysis Is (0.481)

4.2. Analysis of Part Two

\begin{tabular}{|c|c|c|c|c|c|}
\hline & Frequency & Percent & Valid Percent & Cumulative Percent \\
\hline \multirow[t]{14}{*}{ Valid } & 1.00 & 3 & 1.5 & 1.5 & 1.5 \\
\hline & 2.00 & 1 & .5 & .5 & 2.0 \\
\hline & 3.00 & 7 & 3.6 & 3.6 & 5.6 \\
\hline & 4.00 & 26 & 13.3 & 13.3 & 18.9 \\
\hline & 5.00 & 23 & 11.7 & 11.7 & 30.6 \\
\hline & 6.00 & 28 & 14.3 & 14.3 & 44.9 \\
\hline & 7.00 & 20 & 10.2 & 10.2 & 55.1 \\
\hline & 8.00 & 18 & 9.2 & 9.2 & 64.3 \\
\hline & 9.00 & 27 & 13.8 & 13.8 & 78.1 \\
\hline & 10.00 & 20 & 10.2 & 10.2 & 88.3 \\
\hline & 11.00 & 11 & 5.6 & 5.6 & 93.9 \\
\hline & 12.00 & 6 & 3.1 & 3.1 & 96.9 \\
\hline & 13.00 & 6 & 3.1 & 3.1 & 100.0 \\
\hline & Total & 196 & 100.0 & 100.0 & \\
\hline
\end{tabular}

According to the previous table, the number of those who got the score $(13 / 16)$ is only six. Further, the number of respondents who got $(6 / 16)$ is 28 respondents.

\begin{tabular}{|c|c|c|c|c|c|}
\hline & N & Minimum & Maximum & Mean & $\begin{array}{c}\text { Std. } \\
\text { Deviation }\end{array}$ \\
\hline TOTAL SCORE & 196 & 1.00 & 13.00 & 7.1990 & 2.71675 \\
\hline Valid N (listwise) & 196 & & & & \\
\hline
\end{tabular}

Table 11: Shows Descriptive Statistics

The previous Table 11shows the descriptive statistics of the test attached. It shows that the minimum score was $(1 / 16)$ and the maximum score was (13/16). The score mean was (7.19) with a standard deviation (2.716).

\begin{tabular}{|c|c|c|c|c|}
\hline \multicolumn{5}{|c|}{ Descriptive } \\
\hline & & & Statistic & Std. Error \\
\hline \multirow[t]{13}{*}{ TOTAL SCORE } & \multicolumn{2}{|c|}{ Mean } & 7.1990 & .19405 \\
\hline & \multirow{2}{*}{$\begin{array}{l}95 \% \text { Confidence } \\
\text { Interval for Mean }\end{array}$} & Lower Bound & 6.8163 & \\
\hline & & Upper Bound & 7.5817 & \\
\hline & \multicolumn{2}{|c|}{ 5\% Trimmed Mean } & 7.1712 & \\
\hline & \multicolumn{2}{|c|}{ Median } & 7.0000 & \\
\hline & \multicolumn{2}{|c|}{ Variance } & 7.381 & \\
\hline & \multicolumn{2}{|c|}{ Std. Deviation } & 2.71675 & \\
\hline & \multicolumn{2}{|c|}{ Minimum } & 1.00 & \\
\hline & \multicolumn{2}{|c|}{ Maximum } & 13.00 & \\
\hline & \multicolumn{2}{|c|}{ Range } & 12.00 & \\
\hline & \multicolumn{2}{|c|}{ Interquartile Range } & 4.00 & \\
\hline & \multicolumn{2}{|c|}{ Skewness } & .137 & .174 \\
\hline & \multicolumn{2}{|c|}{ Kurtosis } & $-.672-$ & .346 \\
\hline
\end{tabular}

Table 12 


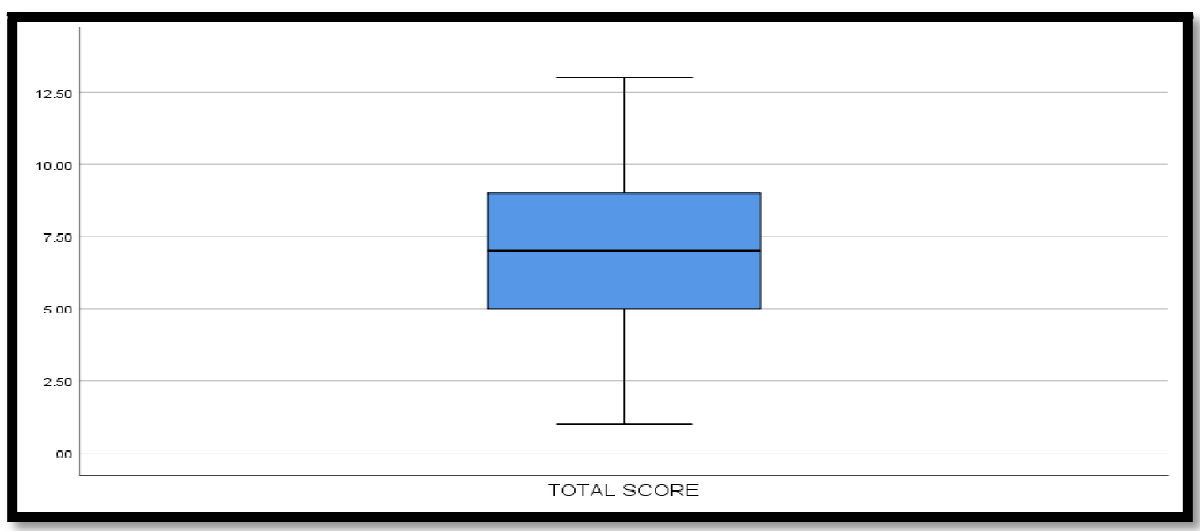

Figure 3: Shows The Score Mean of Respondents' Answers

The previous figure shows the score mean of respondents' answers and the standard deviation of these scores and their distributions.

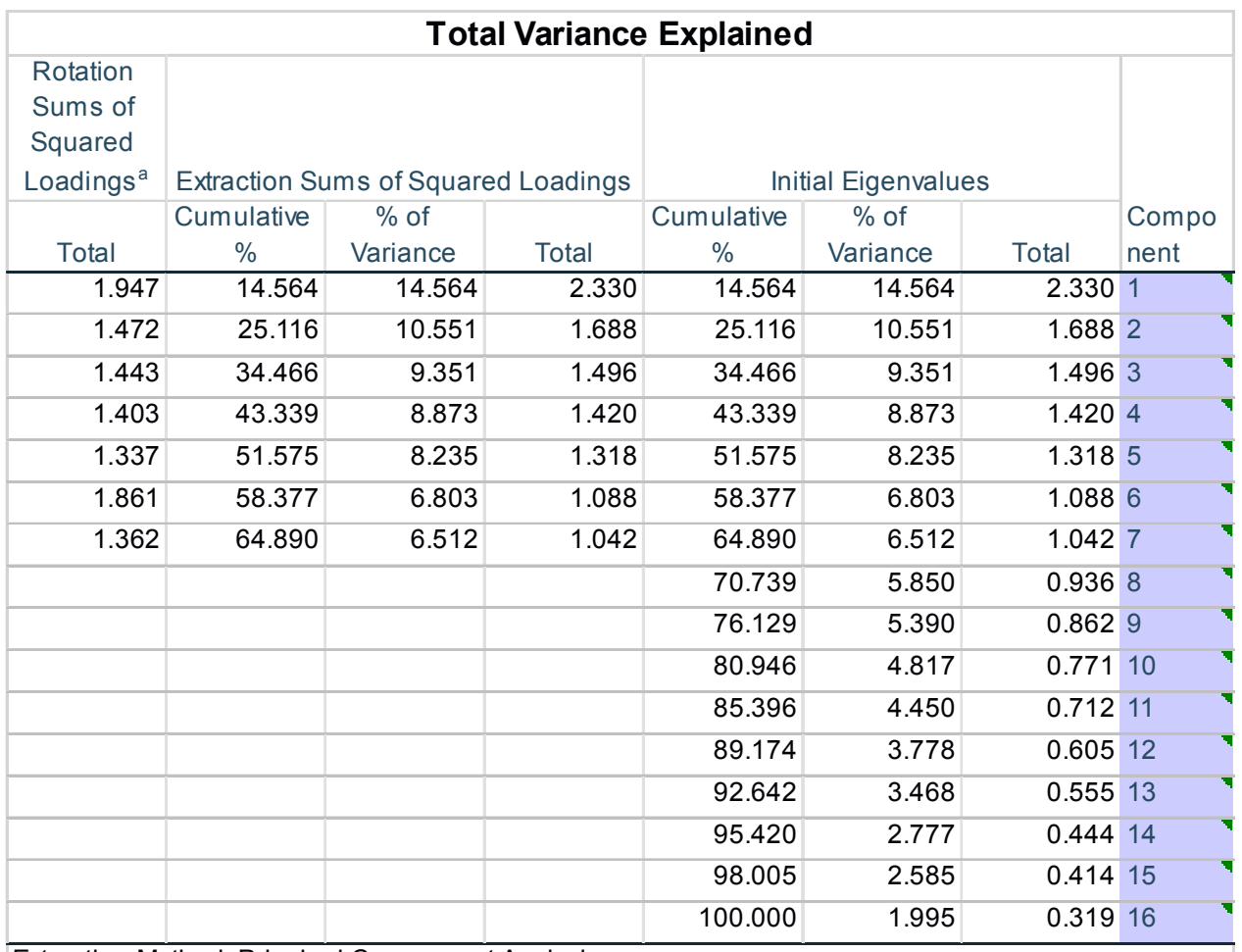

Extraction Method: Principal Component Analysis

a. When components are correlated, sums of squared loadings cannot be added to obtain a total

Table 13: Total Variance Explained

Looking at the Eigenvalues, we can see the first seven components have ICANN values which are higher than (1.0).

\begin{tabular}{|c|c|c|c|c|c|c|c|}
\hline \multicolumn{7}{|c|}{ Component Correlation Matrix } \\
\hline Component & 1 & 2 & 3 & 4 & 5 & 6 & 7 \\
\hline 1 & 1.000 & .079 & $-.053-$ & $-.005-$ & $-.085-$ & $-.165-$ & .059 \\
\hline 2 & .079 & 1.000 & $-.061-$ & $-.077-$ & $-.049-$ & .083 & $-.031-$ \\
\hline 3 & $-.053-$ & $-.061-$ & 1.000 & $-.002-$ & .023 & .101 & $-.014-$ \\
\hline 4 & $-.005-$ & $-.077-$ & $-.002-$ & 1.000 & $-.071-$ & $-.068-$ & $-.021-$ \\
\hline 5 & $-.085-$ & $-.049-$ & .023 & $-.071-$ & 1.000 & .076 & $-.074-$ \\
\hline 6 & $-.165-$ & .083 & .101 & $-.068-$ & .076 & 1.000 & $-.165-$ \\
\hline 7 & .059 & $-.031-$ & $-.014-$ & $-.021-$ & $-.074-$ & $-.165-$ & 1.000 \\
\hline \multicolumn{7}{|c|}{ Extraction Method: Principal Component Analysis. } \\
\hline
\end{tabular}

Table 14: Component Correlation Matrix 


\begin{tabular}{|c|c|c|}
\hline \multicolumn{3}{|c|}{ KMO and Bartlett's Test } \\
\hline \multicolumn{2}{|c|}{ Kaiser-Meyer-Olkin Measure of Sampling Adequacy. } & .545 \\
\hline Bartlett's Test of Sphericity & Approx. Chi-Square & 418.789 \\
\cline { 2 - 3 } & $\mathrm{df}$ & 120 \\
\cline { 2 - 3 } & Sig. & .000 \\
\hline
\end{tabular}

Table 15: KMO and Bartlett's Test

According to the previous table (1.), the factor analysis is $(0.545)$ and sig value is $(0.000)$ which less than $(0.05)$ which indicates that factor analysis is appropriate for our data.

\section{Discussion}

The study aimed at investigating the EFL English teachers' attitudes toward employing the morphological awareness skills in the EFL teachers' daily lessons in Jordan. The research instrument utilized in the research was a reliable and validated questionnaire. The questionnaire comprised two parts, the first one involved 13 items which reflected the broad knowledge of the respondents. The second part included 16 items which tested the tacit and receptive knowledge of the respondents.

\subsection{Analysis of Part One}

According to the responses of part one, the results gained reflected that the majority of respondents confirmed that they studied the course theoretically in their universities. Despite of that, 53\% reported that they do not employ what they studied at universities in their daily lessons at schools. Furthermore, 59 per cent of respondents confirmed that they ignorant of the fact that morphological awareness involves five basic kinds of morphological awareness such as suppletion, compounding, affixation, zero modification and internal change.

When participants were asked about their attitudes on whether morphological awareness is a learnable skill or not, $52 \%$ percent were neutral which reflect a linguistic and methodological crisis among EFL teachers in Jordan. In contrary, only 28 indicated that they agree with the item.

Regarding the appropriate stage for teaching morphological awareness, 80 strongly disagreed with teaching it in the primary stage. Meanwhile, 32 respondents agreed. In contrary, 52 respondents disagreed to be taught in the elementary stage and 65 actually agreed. Pertaining teaching morphological awareness in the secondary stage, 77 participants agreed and 30 participants strongly disagreed.

\subsection{Analysis of Part Two}

Regarding the responses of part two of the questionnaire, they came striking. The maximum score was $(13 / 16)$ with frequency 6 times. Meanwhile, the minimum score was (1/16) seen in table (1.9).

\begin{tabular}{|c|c|c|c|c|c|}
\hline & N & Minimum & Maximum & Mean & Std. Deviation \\
\hline TOTAL SCORE & 196 & 1.00 & 13.00 & 7.1990 & 2.71675 \\
\hline Valid N (listwise) & 196 & & & & \\
\hline
\end{tabular}

Table 16: Shows Descriptive Statistics

\section{Conclusion and Recommendations}

Morphological awareness is a urgent need that should be developed and enriched among EFL teachers. Results gained proved that EFL teachers in Jordan lack of knowledge about morphological awareness in both sides, theoretically and methodologically. The attached test of the questionnaire revealed to what extent the EFL teachers in Jordan demand more training in this field to raise their readiness in teaching morphology.

The EFL supervisors should also prepare and implement training sessions to increase the receptive and productive knowledge of this crucial topic among EFL teachers. Further, teachers are recommended to read some of the modern and updated papers related.

\section{References}

i. Aram, D.and Korat .D. (2009). Literacy Development and Enhancement Across Orthographies and Cultures. Springer.

ii. Baue, I., Lieber, R. and Plag ,I.(2013). The Oxford Reference Guide to English Morphology. Oxford University Press.

iii. Bybee, J.( 1985). Morphology: A Study of the Relation between Meaning and Form. John Benjamins Publishing.

iv. Denham, K.and Lobeck,A.(2010).Linguistics for Everyone: An Introduction. WADSWORTH, CENGAGE Learning.

v. Duncan, L., Traficante, D.and Wilson, M.(2019). Word Morphology and Written Language Acquisition: Insights from Typical and Atypical Development in Different Orthographies. Frontiers in Psychology.

vi. Eppler,E.and Ozón,G. (2013).English Words and Sentences: An Introduction. Cambridge University Press.

vii. Fromkin, V. (2015). An Introduction to Language with Student Resource Access 12 Months.

viii. Lapp, D.and Fisher, D.(2011). Handbook of Research on Teaching the English Language Arts. Routledge , Taylor and Francis.

ix. Lems,V., Miller,D.and Soro,T.(2017).Building Literacy with English Language Learners. Second Edition: Insights from linguistics. Guilford Press.

x. Mansfield, J.(2019). Murrinhpatha Morphology and Phonology. Walter de Gruyter Inc. 
xi. O'connor, R.E. (2007). Teaching Word Recognition. The Guilford Press.

xii. Shearer, B., Carr,D.and Vogt, M.( 2019). Reading Specialists and Literacy Coaches in the Real World: Fourth Edition. Waveland Press.

xiii. Treiman, R.(1993).Beginning to Spell: A Study of First-Grade Children. Oxford University Press.

xiv. Young, V.M.(2012).The Crucial Voice of People Past and Present. Second Edition. Rowman \& Littlefield.

xv. Alshaboul,Y.(2016).Jordanian Pre-service EFL Teachers' Perspectives about Phonological Awareness: Contributions to Reading Development Athens: ATINER'S Conference Paper Series, No:EDU2016-2211.

xvi. Al-Sobhi, B,. and Preece, A. (2018). Teaching English Speaking Skills to the Arab Students in the Saudi School in Kuala Lumpur: Problems and Solutions. International Journal of Education \& Literacy Studies ISSN: 2202-9478.

xvii. Amber, F.H.(2009). Phonological and Morphological Issues in Learners' Performance of English as a Foreign Language: A Case Study of Ninth Grade Students at Taybeh Secondary School for Girls in Ma'an Governorate. Unpublished master thesis. Middle East University, Jordan.

xviii. Bataineh, R, and Kufeiri, Q. (2018).Morphological Awareness as a Potential Catalyst for Jordanian EFL Students' Reading Comprehension. Lublin Studies In Modern Languages and Literature. Volume, 42 Issue,(2), pp 66-80.

xix. Elttayef, A. and Hussein, N. (2017). Arab Learners' Problems in Learning English Language: A Teacher Perspective. Journal of Literature, Languages and Linguistics. Vol.40, 2017. ISSN 2422-8435.

xx. Habeeb,A. and Ghafil, A .(2018). Theories of Distinctive Features, (Unpublished Mater thesis). University of AlQadissiya. Iraq.

xxi. Kirby, J. and Bowers, P.(2010). Effects of Morphological Instruction on Vocabulary acquisition. Read Writ, Volume, 23: pp. 515-537. DOI 10.1007/s11145-009-9172-z. Springer and Science.

xxii. Naseeb, M. and Ibrahim, M.(2017). Morphological Derivations: Learning Difficulties Encountered by Public Secondary School Students in Amman/Jordan. Canadian Center of Science and Education. English Language Teaching; Vol. 10, No. 12.

xxiii. Ramadan, S.(2015). Morphological Errors Made by Jordanian University Students. Al-Zaytoonah Private University of Jordan. Romanian Journal of English Studies. V, 12, issue (1). DOI 10.1515/rjes -2015-0006

xxiv. Salim, J.A.(2013). A Contrastive Study of English-Arabic Noun Morphology. Canadian Center of Science and Education. International Journal of English Linguistics; Vol. 3, No. 3.

xxv. Susanto, A.(2017) The Teaching of Vocabulary: A Perspective. Journal KATA: Vol 1 No. 2. 